\title{
The Effects of Primary Pterygium on Corneal Endothelial Cells Density in Iraqi Eyes
}

\author{
Alyaa Abood Kereem ${ }^{1}$, Imad Salih Mehdy ${ }^{2 *}$, Hayder Sabah AL-Rubaye ${ }^{3}$ \\ ${ }^{1}$ Professor Ophthalmologist at Kufa University, Faculty of Medicine, Iraq \\ ${ }^{2}$ Ophthalmologist, Imam AL-Hussain Medical City, Iraq \\ ${ }^{3}$ Ophthalmologist, Ibn-AL-Haithem Teaching Hospital, Iraq
}

*Corresponding Author: Imad Salih Mehdy, Ophthalmologist, Imam AL-Hussain Medical City, Iraq;

Email: edas66@yahoo.com

Received Date: 13-04-2021; Accepted Date: 04-05-2021; Published Date: 10-05-2021

Copyright $^{\circledR} 2021$ by Mehdy IS, et al. All rights reserved. This is an open access article distributed under the terms of the Creative Commons Attribution License, which permits unrestricted use, distribution, and reproduction in any medium, provided the original author and source are credited.

\begin{abstract}
Pterygium considered as a common inflammatory and proliferative growth that extends across the limbus and can invade the cornea. It had been found that a long standing Pterygium can be associated with the changes in corneal endothelial layer.

Subjects and method: In our study an eighty-one patients (162 eyes) with unilateral pterygium were randomly taken and consecutively enrolled at the out- patient clinic in Ibn Al-Hiatham Eye Teaching Hospital, using specular microscope, the endothelial density, hexagonality and coefficient of variation in cell area were measured for both eyes, using the results of normal eyes for comparison.

Results: This study showed a significant decrease in means of endothelial cell density and \% of hexagonal cells in affected eyes versus healthy eyes (P0.05), mean of endothelial cell density $2385.8 \pm 220.74$ versus $2487.9 \pm 208.2(\mathrm{P}$-value $=0.003)$, mean of $\%$ of hexagonality 46.92 \pm 9.16 versus $53.30 \pm 8.64$ ( $\mathrm{P}<0.001)$. The study showed no significant difference in coefficient of variation of affected eyes versus healthy eyes, $34.86 \pm 5.06$ versus $35.15 \pm 5.50$ $(\mathrm{P}=0.174)$. There were significant differences between means of coefficient of variation by size of pterygium. Type I $32.34 \pm 3.32$, Type II $34.09 \pm 4.58$, type III $38.47 \pm 5.65$ (P0.002). There was significant negative linear correlation between endothelial cell density and duration of pterygium among affected eyes.
\end{abstract}


Conclusion: The long standing pterygia can be associated with reduction in endothelial cell density. This reduction is markedly apparent with the increase in size and duration of pterygium.

\section{Keywords}

UV-B (Ultraviolet Light); CoV (Coefficient of Variation); ECD (Endothelial Cell Density)

\section{Introduction}

Cornea is the transparent front part of the eye that covers the iris, pupil, and anterior chamber. A single hexagonal endothelial corneal layer plays a pivotal role in keeping the corneal clarity, transparency and deturgescence throughout life by constant pumping excess fluid out of the stroma [1]. This lining monolayer of corneal endothelium is emberyologically derived from neural crest [2].

This corneal endothelial layer does not continue for life, so if any damage occurred to these cells, they will not be substituted by cell proliferation, instead of that the damaged cells and the defect area will be replaced and covered by enlargement and spread of adjacent endothelial cells resulting in reduction in Endothelial Cell Density (ECD) [3-5].

The endothelial cells integrity and function are influenced by many factors which can be intrinsic factors like genetics, race, age, or extrinsic factors like inflammation, infection, intraocular surgery, trauma, contact lens etc [3-9]. Also there is a variation in ECD in different areas of endothelial cells, it is highest in periphery, also central ECD is decreasing with age by rate of $0.6 \%$ year, thus, the ECD of 3400 cells by age 15 will decline to 2300 cells $/ \mathrm{mm}^{2}$ by age of 85 year [9].

Race and geographical distribution might influence the ECD, the density in gender and matched people is more in Japanese than in Americans [10,11]. ECD of 400-600 cells $/ \mathrm{mm}^{2}$ is considered critical end point at which endothelial decompensation will start, so in clinical practice measurement of ECD is important for determining the reserve of endothelial function in individual patients [12-14].

It had been found that in healthy endothelial layer about $60 \%$ of cells are hexagonal in shape (by using scanning electronic micrograph), thus hexagonal description to healthy layer of human endothelium though widely used is not precise and accurate description of endothelial cells shape. When there is decrease in number of six-sided cells with relative to increase of cells with more or fewer than six sides the condition is termed pleomorphism.

For example when endothelial cells die because of aging or exposure to stress (contact lens) trauma, surgery or other eye diseases then the remaining cells cannot divide to substitute the dyed cells, instead they are going to enlarge and spread to cover the defect area in order to

Mehdy IS | Volume 2; Issue 2 (2021) | JOAR-2(2)-013 | Research Article

Citation: Mehdy IS, et al. The Effects of Primary Pterygium on Corneal Endothelial Cells Density in

Iraqi Eyes. J Ophthalmol Adv Res. 2021;2(2):1-11.

DOI: http://dx.doi.org/10.46889/JOAR.2021.2201 
maintain intact monolayer of corneal endothelial layer. Not all endothelial cells enlarge in same extent; therefore, some of cells become larger than other. This difference in shape and size of endothelial layer is best calculated by Coefficient of Variation $(\mathrm{CoV})$, which is calculated as the standard deviation of mean cell area divided by the mean cell area. The increase in $\mathrm{CoV}$ is called polymegathism.

The corneal endothelial cells morphology and count can be recorded, studied and measured by non-invasive method using specular microscope, which is of two types contact and non-contact type or by con focal microscope $[15,16]$.

The radiograph captured by specular microscope in young adult should show single endothelial hexagonal cells with approximately identical size and shape $[15,16]$. Analysis of captured image of specular microscope should include corneal cell density which measured as cells $/ \mathrm{mm}^{2}$, cell size (area) mean cell area measured as $\mu \mathrm{m}^{2} /$ cell, variation of cell size as Coefficient of Variation (CoV) (standard deviation of cell areas/mean cell area) and hexagonality (shape pleomorphism) usually measured as a percentage of 6-sided cells.

Pterygium is a common ocular disorder, described as an elevated superficial triangular wing like fibro-vascular growth of conjunctiva onto cornea toward corneal limbus. Studies showed that about ninety percent of pterygia occur at nasal side. Both nasal and temporal pterygia can occur simultaneously in the same eye, but temporal pterygium rarely occurs alone. It has a world-wide distribution, with a prevalence that varies from 0.3 to $29 \%$, but it is more prevalent in countries in area that named by Cameron as pterygium belt [17]. Pterygium aetiology remains exactly uncertain. Many studies proposed many risk factors for the aetiology of pterygium, like: age, race, geographical distribution, out-door occupation due to chronic ultraviolet light exposure (UV-B), dust etc [18-20].

Pterygium-related decrease in ECD might be added to the list of indications for surgical treatment of pterygium [21].

Many theories attempting to disclose the pathological changes seen in pterygium. The main theory suggested that increasing prevalence of pterygium among countries near equatorial areas because of the effect of ultraviolet radiation mainly UV-B is definite risk factor in aetiology of pterygium. Exposure to this radiation as in out-door working causing mutation to gene, p53, tumour suppressing gene which results in abnormal epithelium of pterygium [20]. The prevalence of pterygium increases with age and it is uncommon or even rare in people younger than 20 years old, where the frequency and even severity of disorder significantly reduced [20]. (The world-who described what is called "pterygium belt" which occur between latitudes 370 north and south of the equator. The prevalence is highest in countries occurring in this belt).

Evident-based studies suggest that that human papilloma virus plays a role in pathology of pterygium. These studies declare that pterygium is not as simple degenerative processes but it is rather an uncontrolled proliferation. Metalloproteinase enzyme and tissue inhibitor of metalloproteinase enzyme might play a role in inflammatory processes, tissue destruction of Bowman layer and pterygium invasion of cornea. Other said that the pterygium represents a

Mehdy IS | Volume 2; Issue 2 (2021) | JOAR-2(2)-013 | Research Article 
localized area of limbal stem cells deficiency on surface of cornea, which results in conjunctival invasion into cornea $[22,23]$

In the early stage of the disease, the pterygium is small and asymptomatic, but when it prone to recurrent inflammation and itching then a conservative treatment is required in form of filter eyeglasses against UV radiation and lubricant eye drop. Surgery indicated when visually significant induced astigmatism, encroachment of lesion on visual axis, recurrent significant degree of inflammation and irritation and for cosmoses (when it is large it causes a cosmetic problems on appearance) [24-26].

\section{Objectives of the Study:}

Our purpose in this prospective study is to show the correlation between pterygium and reduction in endothelial cell count, and to calculate the correlation of pterygium and hexagonality, percentage and coefficient of variation, in eyes with unilateral pterygia and the results compared with that of normal eyes, the results are mentioned below (Table 1-5 and Fig. $1-3)$.

\section{Results}

\begin{tabular}{|c|c|c|}
\hline \multicolumn{3}{|c|}{ Socio-demographic variables } \\
\hline Age (years) & $(51.74 \pm 13.06)$ & $(16-76)$ \\
\hline Male & Gender & \\
\hline Female & 45 & $55.60 \%$ \\
\hline Total & 36 & $44.40 \%$ \\
\hline House wife & 81 & $100.00 \%$ \\
\hline Out-door work & Occupation \\
\hline Employee & 32 & $39.50 \%$ \\
\hline Retired & 23 & $28.40 \%$ \\
\hline Student & 3 & $27.20 \%$ \\
\hline Total & 1 & $3.70 \%$ \\
\hline & 81 & $1.20 \%$ \\
\hline Smoker & Smoking & $100.00 \%$ \\
\hline Non smoker & 24 & $29.60 \%$ \\
\hline Ex - smoker & 53 & $65.40 \%$ \\
\hline Total & 4 & $5 \%$ \\
\hline Shows & 81 & $100.00 \%$ \\
\hline
\end{tabular}

Table 1: Shows distribution of patients according to socio-demographic characteristics including (age, gender, occupation and smoking habit). Mean age was $(51.74 \pm 13.06)$ and majority of patients $(55.6 \%)$ were males. 


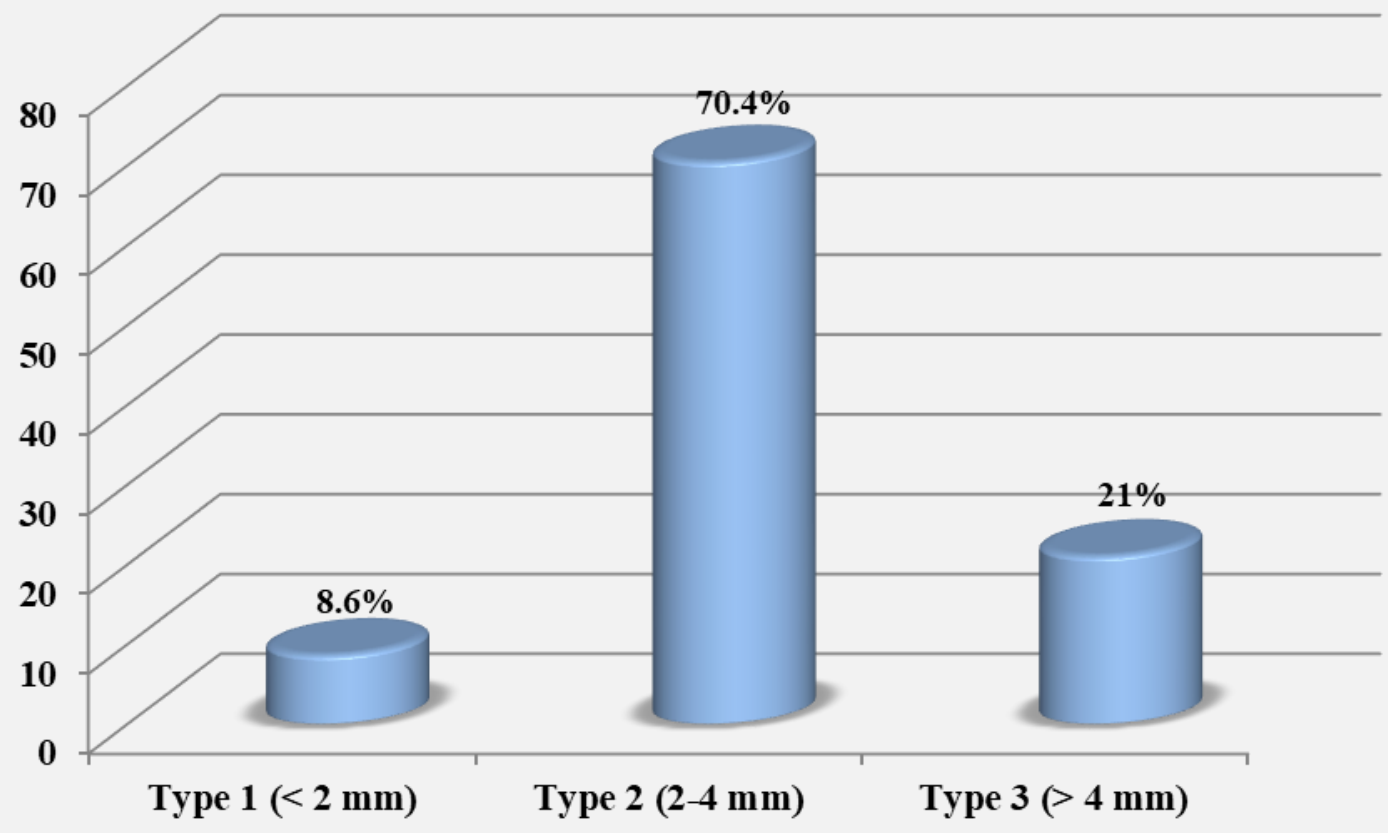

Figure 1: Shows the distribution of patients according to pterygium size. Majority $(70.4 \%)$ of patients presented with type $2(2-4 \mathrm{~mm})$.
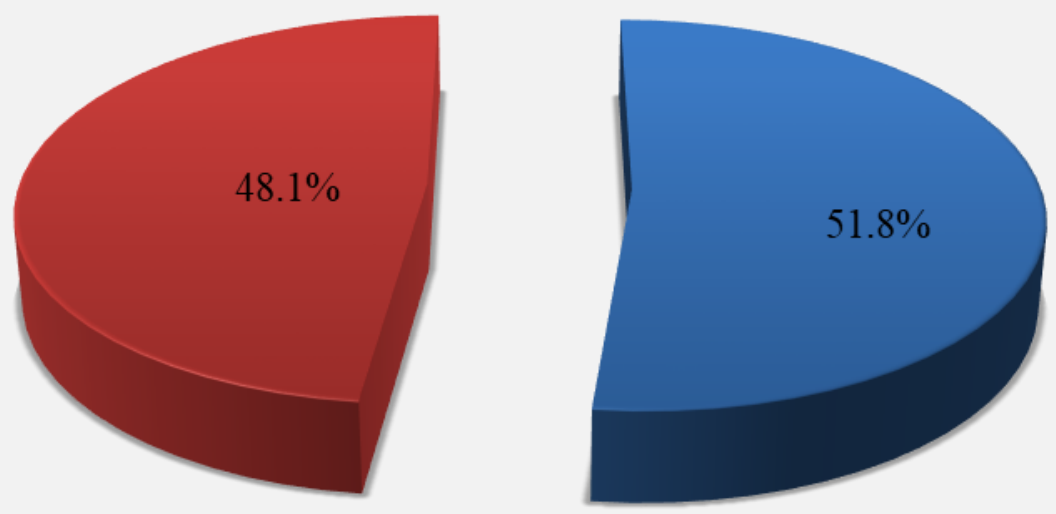

$\square$ Right eye

- Left eye

Figure 2: Shows the distribution of patients according to pterygium side. About $(51.8 \%)$ of patients presented with right eye pterygium. 


\begin{tabular}{|c|c|c|c|c|c|c|}
\hline t-test & $\mathbf{Z}$ & Variable & Type of Eye & $\mathbf{N}$ & Mean \pm SD & P-value \\
\hline \multirow[t]{2}{*}{-3.028} & & $\mathrm{ECD}\left(\mathrm{cell} / \mathrm{mm}^{2}\right)$ & Affected & 81 & $2385.8 \pm 220.74$ & \multirow[t]{2}{*}{0.003} \\
\hline & & & Healthy & 81 & $2487.9 \pm 208.2$ & \\
\hline \multirow[t]{4}{*}{-4.561} & & Hexa (\%) & Affected & 81 & $46.92 \pm 9.16$ & \multirow[t]{2}{*}{$<0.001$} \\
\hline & & & Healthy & 81 & $53.30 \pm 8.64$ & \\
\hline & \multirow[t]{2}{*}{-2.029} & $\mathrm{CoV}(\%)$ & Affected & 81 & $34.86 \pm 5.06$ & \multirow[t]{2}{*}{0.174} \\
\hline & & & Healthy & 81 & $35.15 \pm 5.50$ & \\
\hline
\end{tabular}

Table 2: Shows mean differences of study variables including (ECD, Hexagonality and CoV) by type of eye. There were significant differences between means of ECD and Hexagonality by type of eye.

\begin{tabular}{|c|c|c|c|c|c|}
\hline Variable & Size of Pterygium & $\mathbf{N}$ & Mean \pm SD & F-test & P-value \\
\hline \multirow{3}{*}{$\mathrm{ECD}\left(\mathrm{cell} / \mathrm{mm}^{2}\right)$} & Type 1 & 7 & $2455.6 \pm 240.0$ & \multirow[t]{3}{*}{1.366} & \multirow[t]{3}{*}{0.261} \\
\hline & Type 2 & 57 & $2398.7 \pm 216.8$ & & \\
\hline & Type 3 & 17 & $2313.7 \pm 221.9$ & & \\
\hline \multirow[t]{3}{*}{$\operatorname{Hexa}(\%)$} & Type 1 & 7 & $48.85 \pm 6.96$ & \multirow[t]{3}{*}{0.563} & \multirow[t]{3}{*}{0.572} \\
\hline & Type 2 & 57 & $47.26 \pm 9.38$ & & \\
\hline & Type 3 & 17 & $45.00 \pm 9.35$ & & \\
\hline \multirow[t]{3}{*}{$\mathrm{CoV}(\%)$} & Type 1 & 7 & $32.34 \pm 3.32$ & \multirow[t]{3}{*}{6.645} & \multirow[t]{3}{*}{0.002} \\
\hline & Type 2 & 57 & $34.09 \pm 4.58$ & & \\
\hline & Type 3 & 17 & $38.47 \pm 5.65$ & & \\
\hline \multicolumn{6}{|c|}{${ }^{*} \mathrm{p}$ value $\leq 0.05$ was significant. } \\
\hline
\end{tabular}

Table 3: Shows mean differences of study variables including (ECD, Hexagonality and CoV) by size of pterygium. There were significant differences between means of $\mathrm{CoV}$ by size of pterygium.

\begin{tabular}{|c|c|c|c|c|}
\hline Study Variables & $\mathbf{N}$ & Mean \pm SD & r & P-value \\
\hline ECD & 81 & $2385.8 \pm 220.74$ & -0.381 & $<0.001$ \\
\hline Duration & 81 & $10.19 \pm 4.66$ & & \\
\hline HEXA & 81 & $46.92 \pm 9.16$ & -0.135 & 0.23 \\
\hline Duration & 81 & $10.19 \pm 4.66$ & & 0.175 \\
\hline CoV & 81 & $34.86 \pm 5.06$ & 0.152 & \\
\hline Duration & 81 & $10.19 \pm 4.66$ & \\
\cline { 1 - 2 } & $*$ p value $\leq 0.05$ was significant. \\
\hline
\end{tabular}

Table 4: Shows the correlation between study variables and duration of pterygium for affected eye. There was significant negative linear correlation between ECD and duration of pterygium among affected eye. 


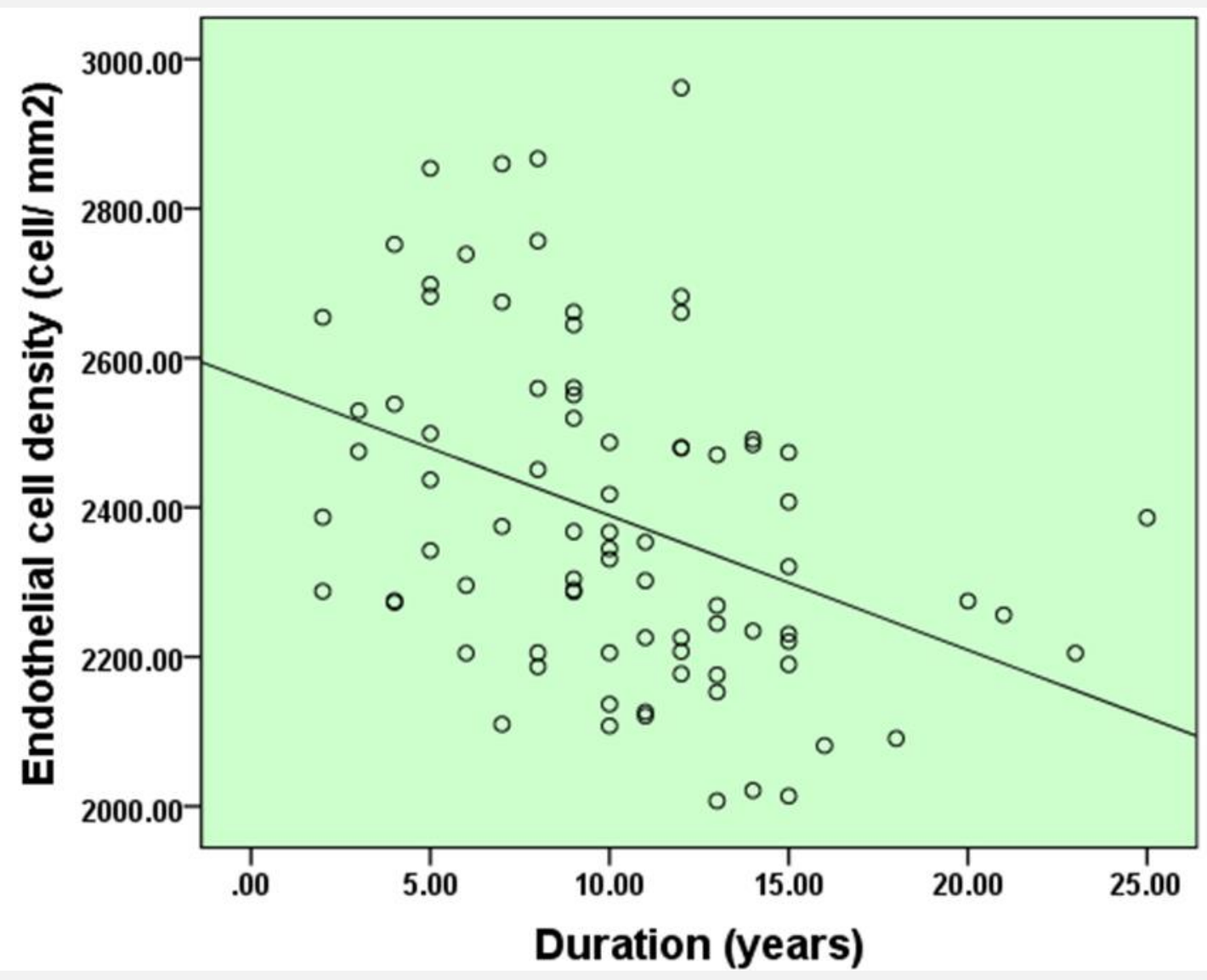

Figure 3: Shows the correlation between ECD and duration of pterygium for affected eye. There was significant negative linear correlation between ECD and duration of pterygium among affected eye. $(\mathrm{r}=-0.381, \mathrm{p}=<0.001)$

\begin{tabular}{|c|c|c|c|c|c|}
\hline Variable & Age groups & $\mathrm{N}$ & Mean \pm SD & t-test & P-value \\
\hline \multirow[t]{2}{*}{$\mathrm{ECD}\left(\mathrm{cell} / \mathrm{mm}^{2}\right)$} & 50 or less & 35 & $2445.01 \pm 228.71$ & \multirow[t]{2}{*}{2.153} & \multirow[t]{2}{*}{0.034} \\
\hline & More than 50 & 46 & $2340.7 \pm 205.68$ & & \\
\hline \multirow[t]{2}{*}{$\operatorname{Hexa}(\%)$} & 50 or less & 35 & $49.34 \pm 7.78$ & \multirow[t]{2}{*}{2.115} & \multirow[t]{2}{*}{0.038} \\
\hline & More than 50 & 46 & $45.08 \pm 9.77$ & & \\
\hline \multirow[t]{2}{*}{$\mathrm{CoV}(\%)$} & 50 or less & 35 & $34.73 \pm 5.33$ & \multirow[t]{2}{*}{-0.204} & \multirow[t]{2}{*}{0.839} \\
\hline & More than 50 & 46 & $34.96 \pm 4.91$ & & \\
\hline \multicolumn{6}{|c|}{$* p$ value $\leq 0.05$ was significant. } \\
\hline
\end{tabular}

Table 5: Shows mean differences of study variables including (ECD, Hexagonality and CoV) by age. There were significant differences between means of ECD and Hexagonality by age. 


\section{Discussion}

Measuring the endothelial cell is an integral part and an accepted practice providing clinical information on endothelial corneal cell layer, which is required to keep the corneal viability, transparency and vital parameter before eye surgery like cataract surgery [27].

Because of the presence of differences in endothelial parameters in many races, the presence of mean normative data on the corneal endothelial parameters is essential. In this respect the data collected may help in the evaluation of the functional endothelial reserve of individuals and may even help in understanding corneal disease in people of different genders, ages, and ethnic groups.

This study provides data on endothelial cell characteristics in the eye with pterygium in comparison to contra lateral normal eye (Table 2).

Unfortunately only few articles paid attention to corneal cell density and other variables in eyes with pterygia to compare with.

Eighty one patients were included in this study (162 eyes) of them 45 were males and 36 were females (this discrepancy might be explained by the fact that the Iraqi female especially in urban area has less out- door UV exposures) .

The patients ages ranging from 16 to76 years with average age of 51.7 years this average is less in comparison to average age (68 years)

In the current study, most of patients were out-door employment and housekeepers living in hot dry climate and might have a significant history of UV-B exposure (Table 1).

This study showed significance negative correlation between age and ECD (Table 5). The endothelial monolayer of cells lining the cornea is non- reproducible after cells damage. Thus, it declines with a rate of $0.6 \%$ /year, 2300 cells $/ \mathrm{mm}^{2}$ at age 85 years. The results of this study consistent with many studies, which showed reduction of ECD with aging.

The mean of ECD in normal eyes was $2487.9 \pm 208.2$ cells per square millimetre whereas; in affected eyes, it was $2385.8 \pm 220.74$ cells per square millimetre (Table 2 ). This reduction in ECD in eye with pterygium in comparison to control eye is in consistence with the findings of other studies by Min-Yen Hsu, et al., 2014 and V Vinod Mootha, et al., 2004 [21,22].

In the current study, there was no significant difference in $\mathrm{CoV}$ in eyes with pterygium in comparison to control eyes (Table 2), this finding was consistence with the study of Min-Yen Hsu, et al., 2014 [22]. Thus, the study was not showing an increase in the variation of cell sizes.

In regards to the size of pterygium, there was a negative correlation between ECD and the size of pterygium (Table 3) but not to a significant degree that was seen in Min-Yen Hsu, et al., 2014 study [22].

The current study showed a negative correlation between ECD and duration of pterygium lesion in affected eyes (Table 4), although this consistent with V Vinod Mootha, et al., 2004 
study, but V Vinod Mootha, et al., speculated that the pterygium must be a long-standing one (about 40 years) in order to influence the ECD [21]. These findings can be explained by fact that the more increasing in size of long standing and advancing pterygia with prolonged exposure to UV-B radiation result in activation of matrix metalloproteinase enzymes leading to more invasion of pterygium into cornea [23, 28-38].

The strength of the study is that it compares normal and diseased eyes in the same individual, thus eliminating the bias of other confounders (Table 2).

\section{Conclusion}

1. The eye with pterygium showed significant decrease in ECD in comparison to normal healthy eye.

2. The eyes with pterygium showed significant reduction in hexagonality percentage in comparison with normal healthy eyes.

3. There was significant negative linear correlation between ECD and duration of pterygium among affected eye.

4. There was negative relationship between ECD and the size of pterygium.

\section{Recommendation}

1. Measurement of ECD should be obtained for any eye with pterygium especially before corneal or refractive surgery.

2. Arrange training courses in measurements of ECD.

3. The specular microscope should be available in ophthalmic outpatient department.

4. Further studies with large cohort should be planned.

\section{Limitations of Study}

The study was limited by:

1. Small sample size.

2. Difficulties in reporting the occupation and precise time of ultraviolet exposure.

3. There was just one specular microscope in the hospital of study thus; the access to this microscope was limited in many times.

\section{References}

1. Teruo N, Shizuya S. Structure of the cornea and sclera in corneal fundamental, diagnosis and management. Volume one Anatomy and Physiology. Ed; Krachmar, Mannis and Holland. Third Ed. 2011;2-3. 
2. Anthony J, Bron, Ramesh C, Trip A Till, Brenda J Tripathi. The cornea and sclera. Wolff's anatomy of the eye and orbit. $8^{\text {th }}$ Edition. Chapman and Hall Medical. 1997;248-62.

3. Lim KS. Corneal endothelial cell damage from glaucoma drainage device materials. Cornea. 2003;22(4):3524.

4. Cantor LB, Rapuano CJ, Cioffi GA. External disease and cornea. Am Acad Ophthalmology. The Eye M.D. Association. 2014-2015:6-9.

5. Sudhir RR, Raman R, Sharma T. Changes in the corneal endothelial cell density and morphology in patients with type 2 diabetes mellitus: a population-based study. Cornea. 2012;31(10):1119-22.

6. Bourne WM. Biology of the corneal endothelium in health and disease. Eye. 2003;17:912-8.

7. Sheng H, Bullimore MA. Factors affecting corneal endothelial morphology. Cornea. 2007;26(5):520-5.

8. Gupta M, Pandey AN, Tyagi R. A study of corneal changes-Endothelial Cell Density (ECD) and Central Corneal Thickness (CCT) in Type-2 DM in relation to Hbalc levels and compare it with healthy individuals. Indian J Clin Exp Ophthalmol. 2016;2(2):123-7.

9. Lee JS, Park WS, Lee SH, Oum BS, Cho BM. A comparative study of corneal endothelial changes induced by different durations of soft contact lens wear. Graefe's Arch Clin Experimental Ophthalmol. 2001;239(1):14.

10. Doughty MJ. Prevalence of 'non-hexagonal'cells in the corneal endothelium of young Caucasian adults, and their inter-relationships. Ophthalmic and Physiological Optics. 1998;18(5):415-22.

11. Higa A, Sakai H, Sawaguchi S, Iwase A, Tomidokoro A, Amano S, et al. Corneal endothelial cell density and associated factors in a population-based study in Japan: the Kumejima study. Am J Ophthalmol. 2010;149(5):794-9.

12. Arıcı C, Arslan OS, Dikkaya F. Corneal endothelial cell density and morphology in healthy Turkish eyes. J Ophthalmol. 2014.

13. Hashemian MN, Moghimi S, Fard MA, Fallah MR, Mansouri MR. Corneal endothelial cell density and morphology in normal Iranian eyes. BMC Ophthalmology. 2006;6(1):1-5.

14. Ohguro N, Matsuda M, Fukuda M. Corneal endothelial changes in patients with chronic renal failure. Am J Ophthalmol. 1999;128(2):234-6.

15. Kirby R Miller. Specular endothelial micrograph - ophthalmic photographers' society.

16. McCarey BE, Edelhauser HF, Lynn MJ. Review of corneal endothelial specular microscopy for FDA clinical trials of refractive procedures, surgical devices and new intraocular drugs and solutions. Cornea. 2008;27(1):1.

17. Liu L, Wu J, Geng J, Yuan Z, Huang D. Geographical prevalence and risk factors for pterygium: a systematic review and meta-analysis. BMJ Open. 2013;3(11).

18. Lim CY, Kim SH, Chuck RS, Lee JK, Park CY. Risk factors for pterygium in Korea: The Korean national health and nutrition examination survey V, 2010-2012. Medicine. 2015;94(32):e1258.

19. Ang M, Li X, Wong W, Zheng Y, Chua D, Rahman A, et al. Prevalence of and racial differences in pterygium: a multiethnic population study in Asians. Ophthalmology. 2012;119(8):1509-15.

20. Chen T, Ding L, Shan G, Ke L, Ma J, Zhong Y. Prevalence and racial differences in pterygium: a crosssectional study in Han and Uygur adults in Xinjiang, China. Investigative Ophthalmology Visual Sci. 2015;56(2):1109-17.

21. Mootha VV, Pingree M, Jaramillo J. Pterygia with deep corneal changes. Cornea. 2004;23(6):635-8.

22. Hsu MY, Lee HN, Liang CY, Wei LC, Wang CY, Lin KH, et al. Pterygium is related to a decrease in corneal endothelial cell density. Cornea. 2014;33(7):712-5.

23. Dushku N, John MK, Schultz GS, Reid TW. Pterygia pathogenesis: corneal invasion by matrix metalloproteinase expressing altered limbal epithelial basal cells. Archives of ophthalmology. 2001;119(5):695-706.

24. Pandey AN, Marken N, Marken R, Pandey BC. A clinical study of pterygium and results of treatment by excision and limbal autograft or augmented with post-Op Mitomycin C. Open J Ophthalmol. 2013;3:97-102.

Mehdy IS | Volume 2; Issue 2 (2021) | JOAR-2(2)-013 | Research Article

Citation: Mehdy IS, et al. The Effects of Primary Pterygium on Corneal Endothelial Cells Density in Iraqi Eyes. J Ophthalmol Adv Res. 2021;2(2):1-11.

DOI: http://dx.doi.org/10.46889/JOAR.2021.2201 
25. Bahuva A, Rao SK. Current concepts in management of pterygium. The Official Scientific J Delhi Ophthalmological Society. 2015;25(2):78-84.

26. Altan-Yaycioglu R, Kucukerdonmez C, Karalezli A, Corak F, Akova YA. Astigmatic changes following pterygium removal: comparison of 5 different methods. Ind J Ophthalmology. 2013;61(3):104-8.

27. Kareem AA, Maan Abdul Ameer Kitab Alged. Evaluation of corneal endothelial cells hysteresis after phacoemulsification. Kufa Med Journal. 2012;15(1):362-71.

28. Brad Bowelling. Cornea. Kanski's clinical ophthalmology. A systematic approach, $8^{\text {th }}$ Edition. Elsevier. 2016:168-9.

29. Thomas C. Use specular microscopy to diagnose corneal disease: specular microscopy is a non-invasive photographic technique that facilitates rapid and accurate diagnosis of corneal endotheliopathies. Review of Optometry. 2009;146(6):69-74.

30. Jackson AJ, Robinson FO, Frazer DG, Archer DB. Corneal guttata: a comparative clinical and specular micrographic study. Eye. 1999;13(6):737-43.

31. Lim KS. Corneal endothelial cell damage from glaucoma drainage device materials. Cornea. 2003;22(4):3524.

32. Norval M, Cullen AP, De Gruijl FR, Longstreth J, Takizawa Y, Lucas RM, et al. The effects on human health from stratospheric ozone depletion and its interactions with climate change. Photochemical and Photobiological Sci. 2007;6(3):232-51.

33. Mohan Ram. Anatomy of Conjunctiva. 2014.

34. Inoue K, Kato S, Inoue Y, Amano S, Oshika T. The corneal endothelium and thickness in type II diabetes mellitus. Jpn J Ophthalmol. 2002;46(1):65-9.

35. Taylor HR, West S, Muñoz B, Rosenthal FS, Bressler SB, Bressler NM. The long-term effects of visible light on the eye. Arch Ophthalmol. 1992;110(1):99-104.

36. Salagar KM, Biradar KG. Conjunctival autograft in primary and recurrent pterygium: a study. JCDR. 2013;7(12):2825-7.

37. Kujur R, Vohra M, Adlakha N. To study the effect of pterygium excision on corneal curvature and contrast sensitivity. Int J Med Res Review. 2015;3(11).

38. Aminlari A, Singh R, Liang D. Management of pterygium. Ophthalmic Pearls Cornea Am Acad Ophthalmol. 2010;37-9. 